\title{
Appendix
}

\section{Key documents}

\author{
Charter of the United Nations \\ San Francisco June 1945 (excerpts)
}

\section{Chapter 1 \\ Purposes and Principles}

\section{Article 2}

The Organization and its Members, in pursuit of the Purposes stated in Article 1, shall act in accordance with the following Principles.

1. The Organization is based on the principle of the sovereign equality of all its Members ...

4. All Members shall refrain in their international relations from the threat or use of force against the territorial integrity or political independence of any state, or in any other manner inconsistent with the Purposes of the United Nations ...

7. Nothing contained in the present Charter shall authorize the United Nations to intervene in matters which are essentially within the domestic jurisdiction of any state or shall require the Members to submit such matters to settlement under the present Charter; but this principle shall not prejudice the application of enforcement measures under Chapter VII. 


\section{Chapter 7}

Action with Respect to Threats to the Peace, Breaches of the Peace, and Acts of Aggression

\section{Article 39}

The Security Council shall determine the existence of any threat to the peace, breach of the peace, or act of aggression and shall make recommendations, or decide what measures shall be taken in accordance with Articles 41 and 42, to maintain or restore international peace and security ...

\section{Article 41}

The Security Council may decide what measures not involving the use of armed force are to be employed to give effect to its decisions, and it may call upon the Members of the United Nations to apply such measures. These may include complete or partial interruption of economic relations and of rail, sea, air, postal, telegraphic, radio, and other means of communication, and the severance of diplomatic relations.

\section{Article 42}

Should the Security Council consider that measures provided for in Article 41 would be inadequate or have proved to be inadequate, it may take such action by air, sea, or land forces as may be necessary to maintain or restore international peace and security. Such action may include demonstrations, blockade, and other operations by air, sea, or land forces of Members of the United Nations ...

\section{Article 51}

Nothing in the present Charter shall impair the inherent right of individual or collective self-defence if an armed attack occurs against a Member of the United Nations, until the Security Council has taken measures necessary to maintain international peace and security. Measures taken by Members in the exercise of this right of self-defence shall be immediately reported to the Security Council and shall not in any way affect the authority and responsibility of the Security Council under the present Charter to take at any time such action as it deems necessary in order to maintain or restore international peace and security. 


\section{Chapter 8 \\ Regional Arrangements}

\section{Article 52}

Nothing in the present Charter precludes the existence of regional arrangements or agencies for dealing with such matters relating to the maintenance of international peace and security as are appropriate for regional action provided that such arrangements or agencies and their activities are consistent with the Purposes and Principles of the United Nations.

\section{Article 53}

The Security Council shall, where appropriate, utilize such regional arrangements or agencies for enforcement action under its authority. But no enforcement action shall be taken under regional arrangements or by regional agencies without the authorization of the Security Council ...

\section{UNSC Resolution 1199 (1998)}

\section{Adopted by the Security Council at its 3930th meeting on 23}

September 1998

The Security Council, Recalling its resolution 1160 (1998) of 31 March 1998,

Having considered the reports of the Secretary-General pursuant to that resolution, and in particular his report of 4 September $1998 \ldots$

Noting with appreciation the statement of the Foreign Ministers of France, Germany, Italy, the Russian Federation, the United Kingdom of Great Britain and Northern Ireland and the United States of America (the Contact Group) of 12 June 1998 at the conclusion of the Contact Group's meeting with the Foreign Ministers of Canada and Japan ... and the further statement of the Contact Group made in Bonn on 8 July $1998 \ldots$

Noting also with appreciation the joint statement by the Presidents of the Russian Federation and the Federal Republic of Yugoslavia of 16 June 1998 ... 
Noting further the communication by the Prosecutor of the International Tribunal for the Former Yugoslavia to the Contact Group on 7 July 1998, expressing the view that the situation in Kosovo represents an armed conflict within the terms of the mandate of the Tribunal,

Gravely concerned at the recent intense fighting in Kosovo and in particular the excessive and indiscriminate use of force by Serbian security forces and the Yugoslav Army which have resulted in numerous civilian casualties and, according to the estimate of the SecretaryGeneral, the displacement of over 230,000 persons from their homes,

Deeply concerned by the flow of refugees into northern Albania, Bosnia and Herzegovina and other European countries as a result of the use of force in Kosovo, as well as by the increasing numbers of displaced persons within Kosovo, and other parts of the Federal Republic of Yugoslavia, up to 50,000 of whom the United Nations High Commissioner for Refugees has estimated are without shelter and other basic necessities,

Reaffirming the right of all refugees and displaced persons to return to their homes in safety, and underlining the responsibility of the Federal Republic of Yugoslavia for creating the conditions which allow them to do so,

Condemning all acts of violence by any party, as well as terrorism in pursuit of political goals by any group or individual, and all external support for such activities in Kosovo, including the supply of arms and training for terrorist activities in Kosovo and expressing concern at the reports of continuing violations of the prohibitions imposed by resolution 1160 (1998),

Deeply concerned by the rapid deterioration in the humanitarian situation throughout Kosovo, alarmed at the impending humanitarian catastrophe as described in the report of the Secretary-General, and emphasizing the need to prevent this from happening,

Deeply concerned also by reports of increasing violations of human rights and of international humanitarian law, and emphasizing the need to ensure that the rights of all inhabitants of Kosovo are respected,

Reaffirming the objectives of resolution 1160 (1998), in which the Council expressed support for a peaceful resolution of the Kosovo problem which would include an enhanced status for Kosovo, a substantially greater degree of autonomy, and meaningful selfadministration, 
Reaffirming also the commitment of all Member States to the sovereignty and territorial integrity of the Federal Republic of Yugoslavia,

Affirming that the deterioration of the situation in Kosovo, Federal Republic of Yugoslavia, constitutes a threat to peace and security in the region,

Acting under Chapter VII of the Charter of the United Nations,

1. Demands that all parties, groups and individuals immediately cease hostilities and maintain a ceasefire in Kosovo, Federal Republic of Yugoslavia, which would enhance the prospects for a meaningful dialogue between the authorities of the Federal Republic of Yugoslavia and the Kosovo Albanian leadership and reduce the risks of a humanitarian catastrophe;

2. Demands also that the authorities of the Federal Republic of Yugoslavia and the Kosovo Albanian leadership take immediate steps to improve the humanitarian situation and to avert the impending humanitarian catastrophe;

3. Calls upon the authorities in the Federal Republic of Yugoslavia and the Kosovo Albanian leadership to enter immediately into a meaningful dialogue without preconditions and with international involvement, and to a clear timetable, leading to an end of the crisis and to a negotiated political solution to the issue of Kosovo, and welcomes the current efforts aimed at facilitating such a dialogue;

4. Demands further that the Federal Republic of Yugoslavia, in addition to the measures called for under resolution 1160 (1998), implement immediately the following concrete measures towards achieving a political solution to the situation in Kosovo as contained in the Contact Group statement of 12 June 1998:

(a) cease all action by the security forces affecting the civilian population and order the withdrawal of security units used for civilian repression;

(b) enable effective and continuous international monitoring in Kosovo by the European Community Monitoring Mission and diplomatic missions accredited to the Federal Republic of Yugoslavia, including access and complete freedom of movement of such monitors to, from and within Kosovo unimpeded by government authorities, and expeditious issuance of appropriate travel documents to international personnel contributing to the monitoring; 
(c) facilitate, in agreement with the UNHCR and the International Committee of the Red Cross (ICRC), the safe return of refugees and displaced persons to their homes and allow free and unimpeded access for humanitarian organizations and supplies to Kosovo;

(d) make rapid progress to a clear timetable, in the dialogue referred to in paragraph 3 with the Kosovo Albanian community called for in resolution 1160 (1998), with the aim of agreeing confidence-building measures and finding a political solution to the problems of Kosovo;

5. Notes, in this connection, the commitments of the President of the Federal Republic of Yugoslavia, in his joint statement with the President of the Russian Federation of 16 June 1998:

(a) to resolve existing problems by political means on the basis of equality for all citizens and ethnic communities in Kosovo;

(b) not to carry out any repressive actions against the peaceful population;

(c) to provide full freedom of movement for and ensure that there will be no restrictions on representatives of foreign States and international institutions accredited to the Federal Republic of Yugoslavia monitoring the situation in Kosovo;

(d) to ensure full and unimpeded access for humanitarian organizations, the ICRC and the UNHCR, and delivery of humanitarian supplies;

(e) to facilitate the unimpeded return of refugees and displaced persons under programmes agreed with the UNHCR and the ICRC, providing State aid for the reconstruction of destroyed homes,

and calls for the full implementation of these commitments;

6. Insists that the Kosovo Albanian leadership condemn all terrorist action, and emphasizes that all elements in the Kosovo Albanian community should pursue their goals by peaceful means only;

7. Recalls the obligations of all States to implement fully the prohibitions imposed by resolution 1160 (1998);

8. Endorses the steps taken to establish effective international monitoring of the situation in Kosovo, and in this connection welcomes the establishment of the Kosovo Diplomatic Observer Mission;

9. Urges States and international organizations represented in the Federal Republic of Yugoslavia to make available personnel to fulfil the 
responsibility of carrying out effective and continuous international monitoring in Kosovo until the objectives of this resolution and those of resolution 1160 (1998) are achieved;

10. Reminds the Federal Republic of Yugoslavia that it has the primary responsibility for the security of all diplomatic personnel accredited to the Federal Republic of Yugoslavia as well as the safety and security of all international and non-governmental humanitarian personnel in the Federal Republic of Yugoslavia and calls upon the authorities of the Federal Republic of Yugoslavia and all others concerned in the Federal Republic of Yugoslavia to take all appropriate steps to ensure that monitoring personnel performing functions under this resolution are not subject to the threat or use of force or interference of any kind;

11. Requests States to pursue all means consistent with their domestic legislation and relevant international law to prevent funds collected on their territory being used to contravene resolution 1160 (1998);

12. Calls upon Member States and others concerned to provide adequate resources for humanitarian assistance in the region and to respond promptly and generously to the United Nations Consolidated Inter-Agency Appeal for Humanitarian Assistance Related to the Kosovo Crisis;

13. Calls upon the authorities of the Federal Republic of Yugoslavia, the leaders of the Kosovo Albanian community and all others concerned to cooperate fully with the Prosecutor of the International Tribunal for the Former Yugoslavia in the investigation of possible violations within the jurisdiction of the Tribunal;

14. Underlines also the need for the authorities of the Federal Republic of Yugoslavia to bring to justice those members of the security forces who have been involved in the mistreatment of civilians and the deliberate destruction of property;

15. Requests the Secretary-General to provide regular reports to the Council as necessary on his assessment of compliance with this resolution by the authorities of the Federal Republic of Yugoslavia and all elements in the Kosovo Albanian community, including through his regular reports on compliance with resolution 1160 (1998);

16. Decides, should the concrete measures demanded in this resolution and resolution 1160 (1998) not be taken, to consider further action and additional measures to maintain or restore peace and stability in the region;

17. Decides to remain seized of the matter. 


\section{Statement \\ Issued at the Extraordinary Ministerial Meeting of the North Atlantic Council Brussels April 1999}

1. The crisis in Kosovo represents a fundamental challenge to the values of democracy, human rights and the rule of law, for which NATO has stood since its foundation. We are united in our determination to overcome this challenge.

2. The Federal Republic of Yugoslavia (FRY) has repeatedly violated United Nations Security Council resolutions. The unrestrained assault by Yugoslav military, police and paramilitary forces, under the direction of President Milosevic, on Kosovar civilians has created a massive humanitarian catastrophe which also threatens to destabilise the surrounding region. Hundreds of thousands of people have been expelled ruthlessly from Kosovo by the FRY authorities. We condemn these appalling violations of human rights and the indiscriminate use of force by the Yugoslav government. These extreme and criminally irresponsible policies, which cannot be defended on any grounds, have made necessary and justify the military action by NATO.

3. NATO's military action against the FRY supports the political aims of the international community: a peaceful, multi-ethnic and democratic Kosovo in which all its people can live in security and enjoy universal human rights and freedoms on an equal basis. In this context, we welcome the statement of the UN Secretary-General of 9th April and the EU Council Conclusions of 8th April.

4. NATO's air strikes will be pursued until President Milosevic accedes to the demands of the international community. President Milosevic knows what he has to do. He must:

- ensure a verifiable stop to all military action and the immediate ending of violence and repression;

- ensure the withdrawal from Kosovo of the military, police and paramilitary forces;

- agree to the stationing in Kosovo of an international military presence;

- agree to the unconditional and safe return of all refugees and displaced persons and unhindered access to them by humanitarian aid organisations;

- provide credible assurance of his willingness to work on the basis of the Rambouillet Accords in the establishment of a 
political framework agreement for Kosovo in conformity with international law and the Charter of the United Nations.

5. Responsibility for the present crisis lies with President Milosevic. He has the power to bring a halt to NATO's military action by accepting and implementing irrevocably the legitimate demands of the international community.

6. We underline that NATO is not waging war against the Federal Republic of Yugoslavia. We have no quarrel with the people of the FRY who for too long have been isolated in Europe because of the policies of their government.

7. We are grateful for the strong and material support we have received from our Partners in the region and more widely in the international community in responding to the crisis.

8. The Alliance shares a common interest with Russia in reaching a political solution to the crisis in Kosovo and wants to work constructively with Russia, in the spirit of the Founding Act, to this end.

9. As a result of President Milosevic's sustained policy of ethnic cleansing, hundreds of thousands of Kosovar people are seeking refuge in neighbouring countries, particularly in Albania and the former Yugoslav Republic of Macedonia. Others remain in Kosovo, destitute and beyond the reach of international relief. These people in Kosovo are struggling to survive under conditions of exhaustion, hunger and desperation. We will hold President Milosevic and the Belgrade leadership responsible for the well-being of all civilians in Kosovo.

10. NATO and its members have responded promptly to this emergency. We have activated with our Partners the Euro-Atlantic Disaster Response Coordination Centre. NATO forces in the former Yugoslav Republic of Macedonia have constructed emergency accommodation for refugees and have cared for them. NATO troops are also being deployed to Albania to support the humanitarian efforts there and to assist the Albanian authorities in providing a secure environment for them. We will sustain and intensify our refugee and humanitarian relief operations in cooperation with the UNHCR, the lead agency in this field. NATO-led refugee and humanitarian aid airlift operations for both Albania and the former Yugoslav Republic of Macedonia are already under way and they will increase. The steps being taken by NATO and the efforts of other international organisations and agencies, including the European Union, are complementary and mutually reinforcing. 
11. We pay tribute to NATO's servicemen and women whose commitment and skill are ensuring the success of NATO's military and humanitarian operations.

12. Atrocities against the people of Kosovo by FRY military, police and paramilitary forces violate international law. Those who are responsible for the systematic campaign of violence and destruction against innocent Kosovar civilians and for the forced deportation of hundreds of thousands of refugees will be held accountable for their actions. Those indicted must be brought before the International Criminal Tribunal for the former Yugoslavia (ICTY) in The Hague in accordance with international law and the relevant resolutions of the United Nations Security Council. Allies reaffirm there can be no lasting peace without justice.

13. NATO has repeatedly stated that it would be unacceptable if the FRY were to threaten the territorial integrity, political independence and security of Albania and the former Yugoslav Republic of Macedonia. We have consulted closely and at a high level with both countries on their specific concerns. We will respond to any challenges by the FRY to the security of Albania and the former Yugoslav Republic of Macedonia stemming from the presence of NATO forces and their activities on their territory.

14. We are concerned over the situation in the Republic of Montenegro. We reaffirm our support for the democratically elected government of President Milo Djukanovic which has accepted tens of thousands of displaced persons from Kosovo. President Milosevic should be in no doubt that any move against President Djukanovic and his government will have grave consequences.

15. The Kosovo crisis underscores the need for a comprehensive approach to the stabilisation of the crisis region in south-eastern Europe and to the integration of the countries of the region into the Euro-Atlantic community. We welcome the EU initiative for a Stability Pact for South-Eastern Europe under the auspices of the OSCE, as well as other regional efforts including the South Eastern Europe Cooperation initiative. We are strengthening the security dialogue between NATO and countries of the region with a view to building a dynamic partnership with them and have tasked the Council in Permanent Session to develop measures to this end. We look forward to a time when the people of Serbia can re-establish normal relations with all the peoples of the Balkans. We want all the countries of southeastern Europe to enjoy peace and security. 


\section{The Alliance's Strategic Concept Washington DC April 1999 (excerpts)}

\section{Introduction}

1. At their Summit meeting in Washington in April 1999, NATO Heads of State and Government approved the Alliance's new Strategic Concept.

2. NATO has successfully ensured the freedom of its members and prevented war in Europe during the 40 years of the Cold War. By combining defence with dialogue, it played an indispensable role in bringing East-West confrontation to a peaceful end. The dramatic changes in the Euro-Atlantic strategic landscape brought by the end of the Cold War were reflected in the Alliance's 1991 Strategic Concept. There have, however, been further profound political and security developments since then.

3. The dangers of the Cold War have given way to more promising, but also challenging prospects, to new opportunities and risks. A new Europe of greater integration is emerging, and a Euro-Atlantic security structure is evolving in which NATO plays a central part. The Alliance has been at the heart of efforts to establish new patterns of cooperation and mutual understanding across the Euro-Atlantic region and has committed itself to essential new activities in the interest of a wider stability. It has shown the depth of that commitment in its efforts to put an end to the immense human suffering created by conflict in the Balkans. The years since the end of the Cold War have also witnessed important developments in arms control, a process to which the Alliance is fully committed. The Alliance's role in these positive developments has been underpinned by the comprehensive adaptation of its approach to security and of its procedures and structures. The last ten years have also seen, however, the appearance of complex new risks to Euro-Atlantic peace and stability, including oppression, ethnic conflict, economic distress, the collapse of political order, and the proliferation of weapons of mass destruction.

4. The Alliance has an indispensable role to play in consolidating and preserving the positive changes of the recent past, and in meeting current and future security challenges. It has, therefore, a demanding agenda. It must safeguard common security interests in an environment of further, often unpredictable change. It must maintain collective defence and reinforce the transatlantic link and ensure a balance 
that allows the European Allies to assume greater responsibility. It must deepen its relations with its partners and prepare for the accession of new members. It must, above all, maintain the political will and the military means required by the entire range of its missions.

5. This new Strategic Concept will guide the Alliance as it pursues this agenda. It expresses NATO's enduring purpose and nature and its fundamental security tasks, identifies the central features of the new security environment, specifies the elements of the Alliance's broad approach to security, and provides guidelines for the further adaptation of its military forces.

\section{Part I - The Purpose and Tasks of the Alliance}

6. NATO's essential and enduring purpose, set out in the Washington Treaty, is to safeguard the freedom and security of all its members by political and military means. Based on common values of democracy, human rights and the rule of law, the Alliance has striven since its inception to secure a just and lasting peaceful order in Europe. It will continue to do so. The achievement of this aim can be put at risk by crisis and conflict affecting the security of the Euro-Atlantic area. The Alliance therefore not only ensures the defence of its members but contributes to peace and stability in this region.

7. The Alliance embodies the transatlantic link by which the security of North America is permanently tied to the security of Europe. It is the practical expression of effective collective effort among its members in support of their common interests.

8. The fundamental guiding principle by which the Alliance works is that of common commitment and mutual co-operation among sovereign states in support of the indivisibility of security for all of its members. Solidarity and cohesion within the Alliance, through daily cooperation in both the political and military spheres, ensure that no single Ally is forced to rely upon its own national efforts alone in dealing with basic security challenges. Without depriving member states of their right and duty to assume their sovereign responsibilities in the field of defence, the Alliance enables them through collective effort to realise their essential national security objectives.

9. The resulting sense of equal security among the members of the Alliance, regardless of differences in their circumstances or in their national military capabilities, contributes to stability in the Euro- 
Atlantic area. The Alliance does not seek these benefits for its members alone, but is committed to the creation of conditions conducive to increased partnership, cooperation, and dialogue with others who share its broad political objectives.

10. To achieve its essential purpose, as an Alliance of nations committed to the Washington Treaty and the United Nations Charter, the Alliance performs the following fundamental security tasks:

Security: To provide one of the indispensable foundations for a stable Euro-Atlantic security environment, based on the growth of democratic institutions and commitment to the peaceful resolution of disputes, in which no country would be able to intimidate or coerce any other through the threat or use of force.

Consultation: To serve, as provided for in Article 4 of the Washington Treaty, as an essential transatlantic forum for Allied consultations on any issues that affect their vital interests, including possible developments posing risks for members' security, and for appropriate coordination of their efforts in fields of common concern.

Deterrence and Defence: To deter and defend against any threat of aggression against any NATO member state as provided for in Articles 5 and 6 of the Washington Treaty.

And in order to enhance the security and stability of the Euro-Atlantic area:

- Crisis Management: To stand ready, case-by-case and by consensus, in conformity with Article 7 of the Washington Treaty, to contribute to effective conflict prevention and to engage actively in crisis management, including crisis response operations.

- Partnership: To promote wide-ranging partnership, cooperation, and dialogue with other countries in the Euro-Atlantic area, with the aim of increasing transparency, mutual confidence and the capacity for joint action with the Alliance.

11. In fulfilling its purpose and fundamental security tasks, the Alliance will continue to respect the legitimate security interests of others, and seek the peaceful resolution of disputes as set out in the Charter of the United Nations. The Alliance will promote peaceful and friendly international relations and support democratic institutions. The Alliance does not consider itself to be any country's adversary. 


\section{Part II - Strategic Perspectives}

\section{The Evolving Strategic Environment}

12. The Alliance operates in an environment of continuing change. Developments in recent years have been generally positive, but uncertainties and risks remain which can develop into acute crises. Within this evolving context, NATO has played an essential part in strengthening Euro-Atlantic security since the end of the Cold War. Its growing political role; its increased political and military partnership, cooperation and dialogue with other states, including with Russia, Ukraine and Mediterranean Dialogue countries; its continuing openness to the accession of new members; its collaboration with other international organisations; its commitment, exemplified in the Balkans, to conflict prevention and crisis management, including through peace support operations: all reflect its determination to shape its security environment and enhance the peace and stability of the Euro-Atlantic area.

13. In parallel, NATO has successfully adapted to enhance its ability to contribute to Euro-Atlantic peace and stability. Internal reform has included a new command structure, including the Combined Joint Task Force (CJTF) concept, the creation of arrangements to permit the rapid deployment of forces for the full range of the Alliance's missions, and the building of the European Security and Defence Identity (ESDI) within the Alliance.

14. The United Nations (UN), the Organisation for Security and Cooperation in Europe (OSCE), the European Union (EU), and the Western European Union (WEU) have made distinctive contributions to Euro-Atlantic security and stability. Mutually reinforcing organisations have become a central feature of the security environment.

15. The United Nations Security Council has the primary responsibility for the maintenance of international peace and security and, as such, plays a crucial role in contributing to security and stability in the Euro-Atlantic area.

16. The OSCE, as a regional arrangement, is the most inclusive security organisation in Europe, which also includes Canada and the United States, and plays an essential role in promoting peace and stability, enhancing cooperative security, and advancing democracy and human rights in Europe. The OSCE is particularly active in the fields of preventive diplomacy, conflict prevention, crisis management, and 
post-conflict rehabilitation. NATO and the OSCE have developed close practical cooperation, especially with regard to the international effort to bring peace to the former Yugoslavia.

17. The European Union has taken important decisions and given a further impetus to its efforts to strengthen its security and defence dimension. This process will have implications for the entire Alliance, and all European Allies should be involved in it, building on arrangements developed by NATO and the WEU. The development of a common foreign and security policy (CFSP) includes the progressive framing of a common defence policy. Such a policy, as called for in the Amsterdam Treaty, would be compatible with the common security and defence policy established within the framework of the Washington Treaty. Important steps taken in this context include the incorporation of the WEU's Petersberg tasks into the Treaty on European Union and the development of closer institutional relations with the WEU.

18. As stated in the 1994 Summit declaration and reaffirmed in Berlin in 1996, the Alliance fully supports the development of the European Security and Defence Identity within the Alliance by making available its assets and capabilities for WEU-led operations. To this end, the Alliance and the WEU have developed a close relationship and put into place key elements of the ESDI as agreed in Berlin. In order to enhance peace and stability in Europe and more widely, the European Allies are strengthening their capacity for action, including by increasing their military capabilities. The increase of the responsibilities and capacities of the European Allies with respect to security and defence enhances the security environment of the Alliance.

19. The stability, transparency, predictability, lower levels of armaments, and verification which can be provided by arms control and non-proliferation agreements support NATO's political and military efforts to achieve its strategic objectives. The Allies have played a major part in the significant achievements in this field. These include the enhanced stability produced by the CFE Treaty, the deep reductions in nuclear weapons provided for in the START treaties; the signature of the Comprehensive Test Ban Treaty, the indefinite and unconditional extension of the Nuclear Non-Proliferation Treaty, the accession to it of Belarus, Kazakhstan, and Ukraine as non-nuclear weapons states, and the entry into force of the Chemical Weapons Convention. The Ottawa Convention to ban anti-personnel landmines and similar agreements make an important contribution to alleviating human suffering. 
There are welcome prospects for further advances in arms control in conventional weapons and with respect to nuclear, chemical, and biological (NBC) weapons ...

\section{Part III - The Approach to Security in the 21st Century}

25. The Alliance is committed to a broad approach to security, which recognises the importance of political, economic, social and environmental factors in addition to the indispensable defence dimension. This broad approach forms the basis for the Alliance to accomplish its fundamental security tasks effectively, and its increasing effort to develop effective cooperation with other European and Euro-Atlantic organisations as well as the United Nations. Our collective aim is to build a European security architecture in which the Alliance's contribution to the security and stability of the Euro-Atlantic area and the contribution of these other international organisations are complementary and mutually reinforcing, both in deepening relations among Euro-Atlantic countries and in managing crises. NATO remains the essential forum for consultation among the Allies and the forum for agreement on policies bearing on the security and defence commitments of its members under the Washington Treaty.

26. The Alliance seeks to preserve peace and to reinforce Euro-Atlantic security and stability by: the preservation of the transatlantic link; the maintenance of effective military capabilities sufficient for deterrence and defence and to fulfil the full range of its missions; the development of the European Security and Defence Identity within the Alliance; an overall capability to manage crises successfully; its continued openness to new members; and the continued pursuit of partnership, cooperation, and dialogue with other nations as part of its co-operative approach to Euro-Atlantic security, including in the field of arms control and disarmament.

\section{The Transatlantic Link}

27. NATO is committed to a strong and dynamic partnership between Europe and North America in support of the values and interests they share. The security of Europe and that of North America are indivisible. Thus the Alliance's commitment to the indispensable transatlantic link and the collective defence of its members is fundamental to its credibility and to the security and stability of the Euro-Atlantic area. 
The Maintenance of Alliance Military Capabilities

28. The maintenance of an adequate military capability and clear preparedness to act collectively in the common defence remain central to the Alliance's security objectives. Such a capability, together with political solidarity, remains at the core of the Alliance's ability to prevent any attempt at coercion or intimidation, and to guarantee that military aggression directed against the Alliance can never be perceived as an option with any prospect of success.

29. Military capabilities effective under the full range of foreseeable circumstances are also the basis of the Alliance's ability to contribute to conflict prevention and crisis management through non-Article 5 crisis response operations. These missions can be highly demanding and can place a premium on the same political and military qualities, such as cohesion, multinational training, and extensive prior planning, that would be essential in an Article 5 situation. Accordingly, while they may pose special requirements, they will be handled through a common set of Alliance structures and procedures.

\section{The European Security and Defence Identity}

30. The Alliance, which is the foundation of the collective defence of its members and through which common security objectives will be pursued wherever possible, remains committed to a balanced and dynamic transatlantic partnership. The European Allies have taken decisions to enable them to assume greater responsibilities in the security and defence field in order to enhance the peace and stability of the Euro-Atlantic area and thus the security of all Allies. On the basis of decisions taken by the Alliance, in Berlin in 1996 and subsequently, the European Security and Defence Identity will continue to be developed within NATO. This process will require close cooperation between NATO, the WEU and, if and when appropriate, the European Union. It will enable all European Allies to make a more coherent and effective contribution to the missions and activities of the Alliance as an expression of our shared responsibilities; it will reinforce the transatlantic partnership; and it will assist the European Allies to act by themselves as required through the readiness of the Alliance, on a case-by-case basis and by consensus, to make its assets and capabilities available for operations in which the Alliance is not engaged militarily under the political control and strategic direction either of the WEU or as otherwise agreed, taking into account the full participation of all European Allies if they were so to choose. 


\section{Conflict Prevention and Crisis Management}

31. In pursuit of its policy of preserving peace, preventing war, and enhancing security and stability and as set out in the fundamental security tasks, NATO will seek, in cooperation with other organisations, to prevent conflict, or, should a crisis arise, to contribute to its effective management, consistent with international law, including through the possibility of conducting non-Article 5 crisis response operations. The Alliance's preparedness to carry out such operations supports the broader objective of reinforcing and extending stability and often involves the participation of NATO's Partners. NATO recalls its offer, made in Brussels in 1994, to support on a case-by-case basis in accordance with its own procedures, peacekeeping and other operations under the authority of the UN Security Council or the responsibility of the OSCE, including by making available Alliance resources and expertise. In this context NATO recalls its subsequent decisions with respect to crisis response operations in the Balkans. Taking into account the necessity for Alliance solidarity and cohesion, participation in any such operation or mission will remain subject to decisions of member states in accordance with national constitutions.

32. NATO will make full use of partnership, cooperation and dialogue and its links to other organisations to contribute to preventing crises and, should they arise, defusing them at an early stage. A coherent approach to crisis management, as in any use of force by the Alliance, will require the Alliance's political authorities to choose and coordinate appropriate responses from a range of both political and military measures and to exercise close political control at all stages ...

36. Russia plays a unique role in Euro-Atlantic security. Within the framework of the NATO-Russia Founding Act on Mutual Relations, Cooperation and Security, NATO and Russia have committed themselves to developing their relations on the basis of common interest, reciprocity and transparency to achieve a lasting and inclusive peace in the Euro-Atlantic area based on the principles of democracy and co-operative security. NATO and Russia have agreed to give concrete substance to their shared commitment to build a stable, peaceful and undivided Europe. A strong, stable and enduring partnership between NATO and Russia is essential to achieve lasting stability in the EuroAtlantic area ... 


\section{Enlargement}

39. The Alliance remains open to new members under Article 10 of the Washington Treaty. It expects to extend further invitations in coming years to nations willing and able to assume the responsibilities and obligations of membership, and as NATO determines that the inclusion of these nations would serve the overall political and strategic interests of the Alliance, strengthen its effectiveness and cohesion, and enhance overall European security and stability. To this end, NATO has established a programme of activities to assist aspiring countries in their preparations for possible future membership in the context of its wider relationship with them. No European democratic country whose admission would fulfil the objectives of the Treaty will be excluded from consideration ...

\section{Part V - Conclusion}

65. As the North Atlantic Alliance enters its sixth decade, it must be ready to meet the challenges and opportunities of a new century. The Strategic Concept reaffirms the enduring purpose of the Alliance and sets out its fundamental security tasks. It enables a transformed NATO to contribute to the evolving security environment, supporting security and stability with the strength of its shared commitment to democracy and the peaceful resolution of disputes. The Strategic Concept will govern the Alliance's security and defence policy, its operational concepts, its conventional and nuclear force posture and its collective defence arrangements, and will be kept under review in the light of the evolving security environment. In an uncertain world the need for effective defence remains, but in reaffirming this commitment the Alliance will also continue making full use of every opportunity to help build an undivided continent by promoting and fostering the vision of a Europe whole and free.

\section{The Treaty on European Union Maastricht December 1991 (excerpt)}

The Union shall define and implement a common foreign and security policy covering all areas of foreign and security policy, the objectives of which shall be: 
- To safeguard the common values, fundamental interests, independence and integrity of the Union in conformity with the principles of the United Nations Charter;

- To strengthen the security of the Union in all ways;

- To preserve peace and strengthen international security;

- To promote international cooperation;

- To develop and consolidate democracy and the rule of law, and respect for human rights and fundamental freedoms.

The common foreign and security policy shall include all questions relating to the security of the Union, including the progressive framing of a common defence policy ... which might lead to a common defence, should the European Council so decide ... The Western European Union (WEU) is an integral part of the development of the Union providing the Union with access to an operational capability ...

\section{Western European Union Petersberg Declaration Bonn June 1992 (excerpt)}

Apart from contributing to the common defence ... military units of WEU member States, acting under the authority of WEU, could be employed for:

- Humanitarian and rescue tasks;

- Peacekeeping tasks;

- Tasks of combat forces in crisis management, including peacemaking.

A Planning Cell will be established ... The Planning Cell will be responsible for preparing contingency plans for the employment of forces under WEU auspices [and] preparing recommendations for the necessary command, control and communication arrangements ...

\section{Ministerial Meeting of the North Atlantic Council Berlin June 1996 (excerpt)}

The Alliance will support the development of the E[uropean] S[ecurity and] D[efence] I[dentity] within NATO by conducting, at the request of and in coordination with the WEU, military planning and exercises for illustrative WEU missions identified by the WEU.

As an essential element of the development of this identity, we will prepare, with the involvement of NATO and the WEU, for WEU-led 
operations (including planning and exercising of command elements and forces). Such preparations within the Alliance should take into account the participation, including in European command arrangements, of all European Allies if they were so to choose ...

\section{Joint Declaration issued at the British-French Summit St Malo December 1998 (excerpt)}

The European Union needs to be in a position to play its full role on the international stage ... To this end, the Union must have the capacity for autonomous action, backed up by credible military forces, the means to decide to use them, and a readiness to do so, in order to respond to international crises.

In order for the European Union to take decisions and approve military action where the [NATO] Alliance as a whole is not engaged, the Union must be given appropriate structures and a capacity for analysis of situations, sources of intelligence, and a capability for relevant strategic planning, without unnecessary duplication, taking account of the existing assets of the WEU and the evolution of its relations with the EU ...

\section{An Alliance for the 21st Century: [NATO] Washington Summit Communiqué Washington DC April 1999 (excerpt)}

We acknowledge the resolve of the European Union to have the capacity for autonomous action so that it can take decisions and approve military action where the Alliance as a whole is not engaged. As this process goes forward, NATO and the EU should ensure the development of effective mutual consultation, cooperation and transparency, building on the mechanisms existing between NATO and the WEU. We therefore stand ready to define and adopt the necessary arrangements for ready access by the European Union to the collective assets and capabilities of the Alliance, for operations in which the Alliance as a whole is not engaged militarily as an Alliance ... 


\section{Presidency Conclusions \\ Cologne European Council \\ June 1999 (excerpt)}

In pursuit of our Common Foreign and Security Policy objectives and the progressive framing of a common defence policy, we are convinced that the [European] Council should have the ability to take decisions on the full range of conflict prevention and crisis management tasks defined in the Treaty on European Union, the 'Petersberg tasks' ...

We are now determined to launch a new step in the construction of the European Union. To this end we task the General Affairs Council to prepare the conditions and the measures necessary to achieve these objectives, including the definition of the modalities for the inclusion of those functions of the WEU which will be necessary for the EU to fulfil its new responsibilities in the area of the Petersberg tasks ...

\section{Presidency Conclusions Helsinki European Council December 1999 (excerpt)}

The European Council underlines its determination to develop an autonomous capacity to take decisions and, where NATO as a whole is not engaged, to launch and conduct EU-led military operations in response to international crises. This process will avoid unnecessary duplication and does not imply the creation of a European army ...

Building on the guidelines established at the Cologne European Council ... the European Council has agreed in particular the following: cooperating voluntarily in EU-led operations, Member States must be able, by 2003, to deploy within 60 days and sustain for at least 1 year military forces of up to 50,000-60,000 persons capable of the full range of Petersberg tasks. New political and military bodies and structures will be established within the Council to enable the Union to ensure the necessary political guidance and strategic direction to such operations ... 


\section{NATO-Russia Relations: A New Quality Russia-NATO Summit Rome May 2002}

At the start of the 21 st century we live in a new, closely interrelated world, in which unprecedented new threats and challenges demand increasingly united responses. Consequently, we, the member states of the North Atlantic Treaty Organization and the Russian Federation are today opening a new page in our relations, aimed at enhancing our ability to work together in areas of common interest and to stand together against common threats and risks to our security. As participants of the Founding Act on Mutual Relations, Cooperation and Security, we reaffirm the goals, principles and commitments set forth therein, in particular our determination to build together a lasting and inclusive peace in the Euro-Atlantic area on the principles of democracy and cooperative security and the principle that the security of all states in the Euro-Atlantic community is indivisible. We are convinced that a qualitatively new relationship between NATO and the Russian Federation will constitute an essential contribution in achieving this goal. In this context, we will observe in good faith our obligations under international law, including the UN Charter, provisions and principles contained in the Helsinki Final Act and the OSCE Charter for European Security.

Building on the Founding Act and taking into account the initiative taken by our Foreign Ministers, as reflected in their statement of 7 December 2001, to bring together NATO member states and Russia to identify and pursue opportunities for joint action at twenty, we hereby establish the NATO-Russia Council. In the framework of the NATO-Russia Council, NATO member states and Russia will work as equal partners in areas of common interest. The NATO-Russia Council will provide a mechanism for consultation, consensus-building, cooperation, joint decision, and joint action for the member states of NATO and Russia on a wide spectrum of security issues in the EuroAtlantic region.

The NATO-Russia Council will serve as the principal structure and venue for advancing the relationship between NATO and Russia. It will operate on the principle of consensus. It will work on the basis of a continuous political dialogue on security issues among its members with a view to early identification of emerging problems, determination of optimal common approaches and the conduct of joint actions, as appropriate. The members of the NATO-Russia Council, acting in 
their national capacities and in a manner consistent with their respective collective commitments and obligations, will take joint decisions and will bear equal responsibility, individually and jointly, for their implementation. Each member may raise in the NATO-Russia Council issues related to the implementation of joint decisions.

The NATO-Russia Council will be chaired by the Secretary General of NATO. It will meet at the level of Foreign Ministers and at the level of Defence Ministers twice annually, and at the level of Heads of State and Government as appropriate. Meetings of the Council at Ambassadorial level will be held at least once a month, with the possibility of more frequent meetings as needed, including extraordinary meetings, which will take place at the request of any Member or the NATO Secretary General.

To support and prepare the meetings of the Council a Preparatory Committee is established, at the level of the NATO Political Committee, with Russian representation at the appropriate level. The Preparatory Committee will meet twice monthly, or more often if necessary. The NATO-Russia Council may also establish committees or working groups for individual subjects or areas of cooperation on an ad hoc or permanent basis, as appropriate. Such committees and working groups will draw upon the resources of existing NATO committees.

Under the auspices of the Council, military representatives and Chiefs of Staff will also meet. Meetings of Chiefs of Staff will take place no less than twice a year, meetings at military representatives level at least once a month, with the possibility of more frequent meetings as needed. Meetings of military experts may be convened as appropriate.

The NATO-Russia Council, replacing the NATO-Russia Permanent Joint Council, will focus on all areas of mutual interest identified in Section III of the Founding Act, including the provision to add other areas by mutual agreement. The work programmes for 2002 agreed in December 2001 for the PJC and its subordinate bodies will continue to be implemented under the auspices and rules of the NATO-Russia Council. NATO member states and Russia will continue to intensify their cooperation in areas including the struggle against terrorism, crisis management, non-proliferation, arms control and confidence-building measures, theatre missile defence, search and rescue at sea, military-to-military cooperation, and civil emergencies. This cooperation may complement cooperation in other fora. As initial steps in this regard, we have today agreed to pursue the following cooperative efforts: 
- Struggle Against Terrorism: strengthen cooperation through a multi-faceted approach, including joint assessments of the terrorist threat to the Euro-Atlantic area, focused on specific threats, for example, to Russian and NATO forces, to civilian aircraft, or to critical infrastructure; an initial step will be a joint assessment of the terrorist threat to NATO, Russia and Partner peacekeeping forces in the Balkans.

- Crisis Management: strengthen cooperation, including through: regular exchanges of views and information on peacekeeping operations, including continuing cooperation and consultations on the situation in the Balkans; promoting interoperability between national peacekeeping contingents, including through joint or coordinated training initiatives; and further development of a generic concept for joint NATO-Russia peacekeeping operations.

- Non-Proliferation: broaden and strengthen cooperation against the proliferation of weapons of mass destruction (WMD) and the means of their delivery, and contribute to strengthening existing non-proliferation arrangements through: a structured exchange of views, leading to a joint assessment of global trends in proliferation of nuclear, biological and chemical agents; and exchange of experience with the goal of exploring opportunities for intensified practical cooperation on protection from nuclear, biological and chemical agents.

- Arms Control and Confidence-Building Measures: recalling the contributions of arms control and confidence- and securitybuilding measures (CSBMs) to stability in the Euro-Atlantic area and reaffirming adherence to the Treaty on Conventional Armed Forces in Europe (CFE) as a cornerstone of European security, work cooperatively toward ratification by all the States Parties and entry into force of the Agreement on Adaptation of the CFE Treaty, which would permit accession by non-CFE states; continue consultations on the CFE and Open Skies Treaties; and continue the NATO-Russia nuclear experts consultations.

- Theatre Missile Defence: enhance consultations on theatre missile defence (TMD), in particular on TMD concepts, terminology, systems and system capabilities, to analyse and evaluate possible levels of interoperability among respective TMD systems, and explore opportunities for intensified practical cooperation, including joint training and exercises.

- Search and Rescue at Sea: monitor the implementation of the NATO-Russia Framework Document on Submarine Crew Rescue, 
and continue to promote cooperation, transparency and confidence between NATO and Russia in the area of search and rescue at sea.

- Military-to-Military Cooperation and Defence Reform: pursue enhanced military-to-military cooperation and interoperability through enhanced joint training and exercises and the conduct of joint demonstrations and tests; explore the possibility of establishing an integrated NATO-Russia military training centre for missions to address the challenges of the 21 st century; enhance cooperation on defence reform and its economic aspects, including conversion.

- Civil Emergencies: pursue enhanced mechanisms for future NATO-Russia cooperation in responding to civil emergencies. Initial steps will include the exchange of information on recent disasters and the exchange of WMD consequence management information.

- New Threats and Challenges: In addition to the areas enumerated above, explore possibilities for confronting new challenges and threats to the Euro-Atlantic area in the framework of the activities of the NATO Committee on Challenges to Modern Society (CCMS); initiate cooperation in the field of civil and military airspace controls; and pursue enhanced scientific cooperation.

The members of the NATO-Russia Council will work with a view to identifying further areas of cooperation.

\section{UNSC Resolution 1244 (1999) (excerpts)}

Adopted by the Security Council at its 4011th meeting on 10 June 1999

The Security Council,

Bearing in mind the purposes and principles of the Charter of the United Nations, and the primary responsibility of the Security Council for the maintenance of international peace and security,

Recalling its resolutions 1160 (1998) of 31 March 1998, 1199 (1998) of 23 September 1998, 1203 (1998) of 24 October 1998 and 1239 (1999) of 14 May 1999, 
Regretting that there has not been full compliance with the requirements of these resolutions,

Determined to resolve the grave humanitarian situation in Kosovo, Federal Republic of Yugoslavia, and to provide for the safe and free return of all refugees and displaced persons to their homes,

Condemning all acts of violence against the Kosovo population as well as all terrorist acts by any party,

Recalling the statement made by the Secretary-General on 9 April 1999, expressing concern at the humanitarian tragedy taking place in Kosovo,

Reaffirming the right of all refugees and displaced persons to return to their homes in safety,

Recalling the jurisdiction and the mandate of the International Tribunal for the Former Yugoslavia,

Welcoming the general principles on a political solution to the Kosovo crisis adopted on 6 May 1999 (S/1999/516, annex 1 to this resolution) and welcoming also the acceptance by the Federal Republic of Yugoslavia of the principles set forth in points 1 to 9 of the paper presented in Belgrade on 2 June 1999 (S/1999/649, annex 2 to this resolution), and the Federal Republic of Yugoslavia's agreement to that paper,

Reaffirming the commitment of all Member States to the sovereignty and territorial integrity of the Federal Republic of Yugoslavia and the other States of the region, as set out in the Helsinki Final Act and annex 2,

Reaffirming the call in previous resolutions for substantial autonomy and meaningful self-administration for Kosovo,

Determining that the situation in the region continues to constitute a threat to international peace and security,

Determined to ensure the safety and security of international personnel and the implementation by all concerned of their responsibilities under the present resolution, and acting for these purposes under Chapter VII of the Charter of the United Nations,

1. Decides that a political solution to the Kosovo crisis shall be based on the general principles in annex 1 and as further elaborated in the principles and other required elements in annex 2;

2. Welcomes the acceptance by the Federal Republic of Yugoslavia of the principles and other required elements referred to in paragraph 1 
above, and demands the full cooperation of the Federal Republic of Yugoslavia in their rapid implementation;

3. Demands in particular that the Federal Republic of Yugoslavia put an immediate and verifiable end to violence and repression in Kosovo, and begin and complete verifiable phased withdrawal from Kosovo of all military, police and paramilitary forces according to a rapid timetable, with which the deployment of the international security presence in Kosovo will be synchronized;

4. Confirms that after the withdrawal an agreed number of Yugoslav and Serb military and police personnel will be permitted to return to Kosovo to perform the functions in accordance with annex 2;

5. Decides on the deployment in Kosovo, under United Nations auspices, of international civil and security presences, with appropriate equipment and personnel as required, and welcomes the agreement of the Federal Republic of Yugoslavia to such presences;

6. Requests the Secretary-General to appoint, in consultation with the Security Council, a Special Representative to control the implementation of the international civil presence, and further requests the Secretary-General to instruct his Special Representative to coordinate closely with the international security presence to ensure that both presences operate towards the same goals and in a mutually supportive manner;

7. Authorizes Member States and relevant international organizations to establish the international security presence in Kosovo as set out in point 4 of annex 2 with all necessary means to fulfil its responsibilities under paragraph 9 below;

8. Affirms the need for the rapid early deployment of effective international civil and security presences to Kosovo, and demands that the parties cooperate fully in their deployment;

9. Decides that the responsibilities of the international security presence to be deployed and acting in Kosovo will include:

(a) Deterring renewed hostilities, maintaining and where necessary enforcing a ceasefire, and ensuring the withdrawal and preventing the return into Kosovo of Federal and Republic military, police and paramilitary forces, except as provided in point 6 of annex 2;

(b) Demilitarizing the Kosovo Liberation Army (KLA) and other armed Kosovo Albanian groups as required in paragraph 15 below; (c) Establishing a secure environment in which refugees and displaced persons can return home in safety, the international civil 
presence can operate, a transitional administration can be established, and humanitarian aid can be delivered;

(d) Ensuring public safety and order until the international civil presence can take responsibility for this task;

(e) Supervising demining until the international civil presence can, as appropriate, take over responsibility for this task;

(f) Supporting, as appropriate, and coordinating closely with the work of the international civil presence;

(g) Conducting border monitoring duties as required;

(h) Ensuring the protection and freedom of movement of itself, the international civil presence, and other international organizations;

10. Authorizes the Secretary-General, with the assistance of relevant international organizations, to establish an international civil presence in Kosovo in order to provide an interim administration for Kosovo under which the people of Kosovo can enjoy substantial autonomy within the Federal Republic of Yugoslavia, and which will provide transitional administration while establishing and overseeing the development of provisional democratic self-governing institutions to ensure conditions for a peaceful and normal life for all inhabitants of Kosovo;

11. Decides that the main responsibilities of the international civil presence will include:

(a) Promoting the establishment, pending a final settlement, of substantial autonomy and self-government in Kosovo, taking full account of annex 2 and of the Rambouillet accords ...

(b) Performing basic civilian administrative functions where and as long as required;

(c) Organizing and overseeing the development of provisional institutions for democratic and autonomous self-government pending a political settlement, including the holding of elections;

(d) Transferring, as these institutions are established, its administrative responsibilities while overseeing and supporting the consolidation of Kosovo's local provisional institutions and other peace-building activities;

(e) Facilitating a political process designed to determine Kosovo's future status, taking into account the Rambouillet accords ...

(f) In a final stage, overseeing the transfer of authority from Kosovo's provisional institutions to institutions established under a political settlement;

(g) Supporting the reconstruction of key infrastructure and other economic reconstruction; 
(h) Supporting, in coordination with international humanitarian organizations, humanitarian and disaster relief aid;

(i) Maintaining civil law and order, including establishing local police forces and meanwhile through the deployment of international police personnel to serve in Kosovo;

(j) Protecting and promoting human rights;

(k) Assuring the safe and unimpeded return of all refugees and displaced persons to their homes in Kosovo;

12. Emphasizes the need for coordinated humanitarian relief operations, and for the Federal Republic of Yugoslavia to allow unimpeded access to Kosovo by humanitarian aid organizations and to cooperate with such organizations so as to ensure the fast and effective delivery of international aid;

13. Encourages all Member States and international organizations to contribute to economic and social reconstruction as well as to the safe return of refugees and displaced persons, and emphasizes in this context the importance of convening an international donors' conference, particularly for the purposes set out in paragraph 11 (g) above, at the earliest possible date;

14. Demands full cooperation by all concerned, including the international security presence, with the International Tribunal for the Former Yugoslavia;

15. Demands that the KLA and other armed Kosovo Albanian groups end immediately all offensive actions and comply with the requirements for demilitarization as laid down by the head of the international security presence in consultation with the Special Representative of the Secretary-General;

16. Decides that the prohibitions imposed by paragraph 8 of resolution 1160 (1998) shall not apply to arms and related matériel for the use of the international civil and security presences;

17. Welcomes the work in hand in the European Union and other international organizations to develop a comprehensive approach to the economic development and stabilization of the region affected by the Kosovo crisis, including the implementation of a Stability Pact for South Eastern Europe with broad international participation in order to further the promotion of democracy, economic prosperity, stability and regional cooperation;

18. Demands that all States in the region cooperate fully in the implementation of all aspects of this resolution; 
19. Decides that the international civil and security presences are established for an initial period of 12 months, to continue thereafter unless the Security Council decides otherwise;

20. Requests the Secretary-General to report to the Council at regular intervals on the implementation of this resolution, including reports from the leaderships of the international civil and security presences, the first reports to be submitted within 30 days of the adoption of this resolution;

21. Decides to remain actively seized of the matter.

\section{Stability Pact for South Eastern Europe Cologne June 1999 (excerpts)}

\section{Principles and Norms}

5. We solemnly reaffirm our commitment to all the principles and norms enshrined in the UN Charter, the Helsinki Final Act, the Charter of Paris, the 1990 Copenhagen Document and other OSCE documents, and, as applicable, to the full implementation of relevant UN Security Council Resolutions, the relevant conventions of the Council of Europe and the General Framework Agreement for Peace in Bosnia and Herzegovina, with a view to promoting good neighbourly relations.

6. In our endeavours, we will build upon bilateral and multilateral agreements on good neighbourly relations concluded by States in the region participating in the Pact, and will seek the conclusion of such agreements where they do not exist. They will form an essential element of the Stability Pact.

7. We reaffirm that we are accountable to our citizens and responsible to one another for respect for OSCE norms and principles and for the implementation of our commitments. We also reaffirm that commitments with respect to the human dimension undertaken through our membership in the OSCE are matters of direct and legitimate concern to all States participating in the Stability Pact, and do not belong exclusively to the internal affairs of the State concerned. Respect for these commitments constitutes one of the foundations of international order, to which we intend to make a substantial contribution.

8. We take note that countries in the region participating in the Stability Pact commit themselves to continued democratic and 
economic reforms, as elaborated in paragraph 10, as well as bilateral and regional cooperation amongst themselves to advance their integration, on an individual basis, into Euro-Atlantic structures. The EU Member States and other participating countries and international organisations and institutions commit themselves to making every effort to assist them to make speedy and measurable progress along this road. We reaffirm the inherent right of each and every participating State to be free to choose or change its security arrangements, including treaties of alliance as they evolve. Each participating State will respect the rights of all others in this regard. They will not strengthen their security at the expense of the security of other States.

\section{Objectives}

9. The Stability Pact aims at strengthening countries in South Eastern Europe in their efforts to foster peace, democracy, respect for human rights and economic prosperity, in order to achieve stability in the whole region. Those countries in the region who seek integration into Euro-Atlantic structures, alongside a number of other participants in the Pact, strongly believe that the implementation of this process will facilitate their objective.

10. To that end we pledge to cooperate towards:

- preventing and putting an end to tensions and crises as a prerequisite for lasting stability. This includes concluding and implementing among ourselves multilateral and bilateral agreements and taking domestic measures to overcome the existing potential for conflict;

- bringing about mature democratic political processes, based on free and fair elections, grounded in the rule of law and full respect for human rights and fundamental freedoms, including the rights of persons belonging to national minorities, the right to free and independent media, legislative branches accountable to their constituents, independent judiciaries, combating corruption, deepening and strengthening of civil society;

- creating peaceful and good-neighbourly relations in the region through strict observance of the principles of the Helsinki Final Act, confidence building and reconciliation, encouraging work in the OSCE and other fora on regional confidence building measures and mechanisms for security cooperation; 
- $\quad$ preserving the multinational and multiethnic diversity of countries in the region, and protecting minorities;

- creating vibrant market economies based on sound macro policies, markets open to greatly expanded foreign trade and private sector investment, effective and transparent customs and commercial/ regulatory regimes, developing strong capital markets and diversified ownership, including privatisation, leading to a widening circle of prosperity for all our citizens;

- fostering economic cooperation in the region and between the region and the rest of Europe and the world, including free trade areas;

- $\quad$ promoting unimpeded contacts among citizens;

- combatting organised crime, corruption and terrorism and all criminal and illegal activities;

- preventing forced population displacement caused by war, persecution and civil strife as well as migration generated by poverty;

- ensuring the safe and free return of all refugees and displaced persons to their homes, while assisting the countries in the region by sharing the burden imposed upon them;

- creating the conditions, for countries of South Eastern Europe, for full integration into political, economic and security structures of their choice ... 